\title{
Identifying the Implementation of Hindu Cultural Values (Asta Brata)-Based Leadership Style as Used by Principals of Public Junior High Schools in Tabanan Regency
}

\author{
I Nyoman Natajaya* \\ Educational Administration Study Program \\ Ganesha University of Education \\ Singaraja, Indonesia \\ *nyomannatajaya52@gmail.com
}

\begin{abstract}
This study aimed at finding out the implementation of Hindu cultural values (Asta Brata)-based leadership style as used by principals of public junior high schools in Tabanan regency. This study used a descriptive research design and was ex-post facto in its nature. The population of the schools in this study was all of public junior high schools in Tabanan region, the school sample was determined by purposive random sampling, which consisted of 6 schools in which 2 schools for each of the following locations: the regency town, the district town, and the village. The teacher population in this study was all teachers who teach at public junior high schools which were selected as school sample. The teacher sample was also determined by using purposive random sampling technique, which in this study consisted of 40 teachers from each of the following locations: the regency capital and the district towns, and 30 teachers from the villages. So, the number of the teacher sample in all was 220 . The data were collected using a questionnaire which had been tested for its validity and reliability, which was supplemented with interview and in-depth discussion. The data were analyzed using a descriptive analysis and qualitative interpretation. The results showed that the perception of the teachers of the implementation of Hindu cultural values as used by the principals of public junior high schools in the regency and district towns can be categorized into the very good category, and the perception of the teachers of the implementation of Hindu cultural values as used by the principals of public junior high schools in the villages can be categorized into the very good category too.
\end{abstract}

Keywords-leadership style, hindu culture, asta brata principals

\section{INTRODUCTION}

Principals as educational staff are required to understand the concept of education which is not limited to the teaching process, but it also includes the process of giving guidance, motivation, inviting, directing, giving good examples, and the giving of influence to the students, the employees and teachers as their subordinates. The principal's guidance toward the students, and his or her subordinates is important, and more important than this is how the guidance process is done. So is the interpretation of the guidance which cannot be separated from the concept of guidance put forward by $\mathrm{Ki}$ Hajar Dewantara in his system among. He stated that the principal has to be able to give examples, can give influence, and can control the students and the subordinates [1]. The principal has to be able to create and develop a conducive atmosphere at his or her school. The principal and the subordinates in principle have to able to mutually make progress to reach a higher level in morality and motivation [2]. Leaders have to have a perspective far ahead into the future and attempt to improve and develop organizations for the future. The leaders and their subordinates have to stimulate each other to improve morality and motivation that are related to their main jobs and functions [3]. Principals have to prioritize the giving of opportunities and or motivation to all elements at the schools and are willing without coercion to participate optimally in an effort to reach the goals of the schools [4]. Principals as leaders have to be able to help the staff members by developing and maintaining the school culture which is collaborative and professional, to help the teachers develop, and solve problems together [5]. The principals have to be able to create an atmosphere of order, discipline, and can create a promising condition for the staff and students, good relations among staff members, commitment among the staff members and students to achieve the goals, provide enough time for staff directions and staff development [6].

Likewise, the principal as a leader must be able to apply the leadership of Asta Brata, which is one the leaderships that comes from Hindu religious literature and culture that has been known by Indonesians especially by those who are Hindus, since it has universal truths and noble values.

Then Asta Brata can be presented by referring to the explanation given in the literatures [7-9] as follows: 
1) Indra Brata. In Manusemerti Chapter IX it is stated as follows: "Like Indra that makes rain in the rainy season a king places Indra's position who gives away wealth to His kingdom". Then in Ramayana XXIV: 58 it is stated: It is like this the task of God Indra that has to be followed, that is, by giving away wealth to His people, you should imitate this act of God Indra, you should bestow your wealth to make your people prosper".

According to Indra Brata's teaching, a leader should have the character which is capable of meeting the basic needs of the community economically, giving the people a security feeling, improving the intelligence of the people, paying great attention to the people at the low level, often going down to them to absorb their aspirations as inputs in making policies and being able to waste away all forms of deviances and misappropriations that block the prosperity and justice in the society. As a leader you have to behave like rain water that comes down from the sky that gives coolness, wipes away aridity as to create physical and spiritual welfare justly down to the lowest level and in all directions.

2) Yama Brata. In Manusmerti Chapter IX: 307 it is stated as follows: Like Yama who acts firmly to friends and enemies, thus all the people are controlled by the king according to his status like that of God Yama." Then in Ramayana XXIV: 54 it is stated: In facing evil acts you should use the teaching of Yama Brata, that is, punishing every thievery, especially when it has caused a death. The people who were involved and have committed a wrong deed should also be punished. Every person who is screwing up the country deserves a death sentence".

According to the teaching of Yama Brata the leader has to have the quality of order like a star that is able to create order based on a law. All people including the ruler has to obey the law as the means to create order and development. None has impunity, standing over the law, or outside the law. Thus, a leader has to be able to reinforce legal authority, using the law as the basis of his or her actions, treating all people equally before the law, behaving justly by respecting human dignity.

3) Surya Brata. In Manusmerti Chapter IX: 305 it is stated as follows: "Like Surya, for eight months absorbing water by His invisible light and heat. He slowly collects taxes from His people, according to His status like the sun. "Then in Ramayana XXIV: 55 it is stated: "Sun God always absorbs water slowly, not hurriedly, so should you do if you want something, you should take it like what the sun does, that is doing it gently.

According to the teaching of Surya Brata a leader is expected to have a quality that is capable of digging the potentiality of tax as the source of revenue and source for development which is collected justly, it should be done well, not hurriedly, without any good planning and a clear objective, taking away something from the people. Every source of revenue that is collected from the people has to be returned to them, for their welfare. Thus, like the sun that absorbs water from the ocean, then the water becomes a cloud, and finally it turns into rain that falls down to refresh all things on the earth. Thus the leader is also required to protect the people from any form of crime, and can give energy to the people as to make them have motivation and excitement to develop by relying on their own abilities.

4) Chandra Brata. In Manusmerti Chapter IX: 309 it is stated as follows: "He is the king who has the position of Goddess Candra, whose people welcome Him warmly, as people who are happy to see the full moon". Then in Ramayana XXIV: 56 it is stated: the main action of Goddess Candra is to make all the world feel happy. Thus are your actions, they should always be sweet like the water of life, respect the elders and the wise and be generous to them."

According to the teaching of Candra Brata then a leader has to act like the moon that is always sympathetic, respects the elder and especially those who have done a lot for the society, the priests, the intellectuals, since they guide the spirit and educate the people. The leader has to be able to give a cooling light and make the people happy.

5) Vhayu Brata (Maruta). In Manusmerti Chapter IX: 306 it is stated as follows: "Like whayu (wind) moving to every direction, entering the living creatures as the breath for all of them, so should the king be moving to all directions, since it is this position that is like that of the wind". Then in Ramayana XXIV: 56 it is stated: You should behave like the wind if you want to investigate others' behaviors. This investigation should be done politely, unobvious. That is what is called Bayu Brata that has a high value and brings a very good service."

According to Vhayu Brata teaching, a leader has to have to ability to rule all of his or her region, people and becomes the breath of life of all creatures. Secondly the leader has to pay official and unofficial visits, always communicate with his or her people reciprocally. Thus, the leader is like the wind which is present anywhere understanding what is alive and developing and happening in his or her society, both in the form of problems and complaints which can block the people's expectation. Supervision is also very important to assess what has been achieved, to evaluate and improve various policies that are deemed necessary. he supervision is done not only systematically, but also personally, so that although it cannot be seen, it is felt to exist like the wind which is present everywhere.

6) Bhumi (Dhanada). In Manusmerti Chapter IX: 331 it is stated as follows: "Like Bhumi that supports all living creatures justly, so should the king do to His people according to His position as Mother Earth. Then, in Ramayana: 58 it is stated: Enjoy this wealth with moderation, both in food, drink, dress and jewelry like Goddess Dhanada who should be held as the model."

7) Varuna Brata. In Manusmerti Chapter I: 308 it is stated as follows: "Like the sinners who look to be tied to the rope by 
Varuna, so should the king do punish the criminals according to His status which is like that of Varuna". Then in Ramayana XXIV: 58 is stated: God Varuna holds a poisonous weapon, that is, Nagapasa that can tie tightly, you should use the model of the nature of Nagapasa, that is, you have to tie tightly the criminals."

According to Varuna Brata a leader has to have the quality like that of the ocean that always fights all types of crime without any compromise. The leader has to be firm in punishing crimes, tying tightly the bad people, the leader has to be able to prevent the sources of crime to create a secure and orderly social intercourse.

8) Agni Brata. In Manusmerti Chapter IX: 310 it is stated as follows: "If the majesty is enthusiastic in destroying criminals and has the powerful strength and able to eliminate the bad authorities, then His quality is like that of Agni". Then in Ramayana XXIV: 60 it is stated: "the major responsibility of Agni (Fire) is to always burn its challenge. The bravery and toughness to face the enemies, that is what Fire is, anyone that you fight against will surely be destroyed. That what is called Agni Brata."

Based on the quotations above, it can be concluded that a leader has to be like fire that has the quality and ability in unifying the country and protecting it from any threat that comes from inside and outside. The leader has to have the ability and strength to eradicate all forms of crimes for the victory of the society.

That is the description of Asta Brata leadership pattern that can be identified and translated into values, norms, rules, directives, guides for a leader in performing his or her duty as principal. Perhaps only a small number of the values that have been dug and developed, especially the elements of the Asta Brata leadership which is called as the reflection and manifestation of the natural qualities or God according to Hindu religious teaching who has the most perfect qualities. Thus, the values, norms, rules, directives, guides mentioned by the scholars are only the small part, serving only as stimulants in order that the community, especially Balinese can participate in studying and discussing them from various sides.

\section{METHODS}

This study used a descriptive research design and was $e x$ post facto in nature. The population was all of public junior high schools in Tabanan regency, the school sample was determined by using purposive random sampling technique, that is, 6 schools: 2 schools located in the regency town, 2 in district towns, and two in the villages. The teacher population in this study was all teachers who teach at public junior high schools selected as the school sample. The teacher sample was also determined by using a purposive random sampling technique, in which from every school located in the regency towns, in the district towns 40 teachers were selected and from the schools located in the villages 30 teachers were selected each. Thus, the whole number of the sample of teachers was
220. The data were collected by using questionnaire that has been tried out and tested in terms of validity and reliability, supplemented by interview and in-depth discussion. The data were analyzed using descriptive analysis and qualitative interpretation.

\section{RESULTS AND DISCUSSION}

Based on the results of analysis of the data on the teachers' perception of the implementation of Hindu cultural valuesbased leadership style as used by principals of public junior high schools in Tabanan regency, the results showed that the perception of the teachers of public junior high schools in Tabanan regency of the implementation of Hindu cultural values-based leadership style can be categorized as very good, that of the teachers of public junior high schools in the district towns of the implementation of Hindu cultural values- based leadership style can be categorized as very good, and that of the teachers of public junior high schools in the villages can be categorized as very good too.

If the findings above is examined more closely, it seems that it is logical since if it is seen from Hindu cultural valuesbased leadership from the indicators that are contained in it, it seems that there is there are some similarities between it and those of modern leadership style values and they are a combination of modern leadership style values such as those of situational leadership, visionary leadership, transactional and transformational leadership that are being introduced and asked to be implemented by the government. Thus, actually the implementation of Hindu cultural values-based leadership style that come from belief, morality and religiosity that is supported by modern leadership styles that have rationality values, then it will become very good since it has a strong rational foundation. It seems that it is this understanding that the principals have, so that they are very good in implementing Hindu cultural valuesbased leadership style in the field. This finding is also supported by some study results done by the postgraduate students of the Educational Administration Program in the frame of writing their theses that also find that the principals' leadership style was very good.

Although the findings of this study in general conclude that the perception of teachers of the implementation of Hindu cultural values-based leadership style as used by public junior high schools in Tabanan regency is very good, if closely examined actually in certain indicators there are teachers who perceived it to be rather weak since actually the weak leadership behavior is not included in the authority of a principal. How a principal can meet the welfare of the school, like the meeting of the physical facilities of the school in the form of buildings, laboratories, libraries and equipment and the welfare of the employees and teachers in the form of economic rewards, etc. since these are under the authority of and are dependent on the regional government. Thus, it is logical that the principals are very weak in creating the welfare of the school. 


\section{CONCLUSION}

Based on the results of the data analysis and discussion of the results, then it can be concluded as follows. In general, it can be concluded that the perception of the teachers of the implementation of Hindu cultural values- based leadership as used by the principals of public junior high schools can be categorized into very good. That the perception of the teachers of the implementation of Hindu cultural values- based leadership as used by the principals of public junior high schools in the regency towns can be categorized into very good. That the perception of the teachers of the implementation of Hindu cultural values- based leadership as used by the principals of public junior high schools in the district towns can be categorized into very good. And, the perception of the teachers of the implementation of Hindu cultural values -based leadership as used by the principals of public junior high schools in the villages can be categorized into very good.

\section{REFERENCES}

[1] R.K. Soetjipto, "Profesi keguruan". Jakarta: Rineka Cipta. 1999.

[2] A.C.T. Komariah, "Visionary leadreship menuju sekolah efektif". Jakarta: Bumi Aksara. 2006.

[3] S. Danim, "Menjadi komunitas pembelajar, kepemimpinan transformasional dalam komunitas organisasi pembelajaran". Jakarta: Bumi Aksara. 2005.

[4] S. Danim, and Suparno, "Manajemen dan kepemimpinan transformasional kepala sekolah". Jakarta: Rineka Cipta. 2009.

[5] H. Usman, "Manajemen, teori, praktik, dan riset pendidikan". Jakarta: Bumi Akasara. 2006.

[6] Raihani, "Kepemimpinan sekolah transformtif”. Yogyakarta: LkiS. 2010 .

[7] O. Mahendra, Ajaran hindu tentang kepemimpinan konsep negara dan wiweka. Jakarta: Swadaya. 2001.

[8] A.G.K. Wiratmadja, "Kepemimpinan hindu". Denpasar: Yayasan Dharma Naradha. 1995.

[9] K.G. Ariasna, “Kepemimpinan hindu”. Surabaya: Paramita. 1998. 